\title{
19
}

\section{觀 血的骨接合術ノ一法}

マグヌス氏法及ビ其ノ應用

\author{
甫立松本病院 \\ 川瀨潔
}

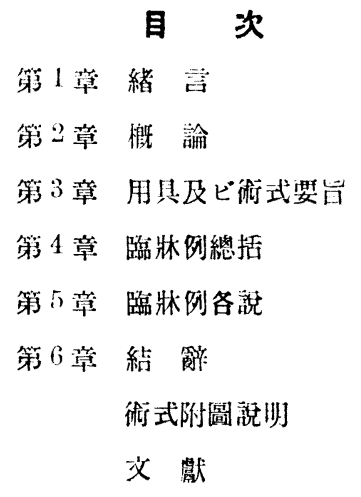

\section{第1章 緒 言}

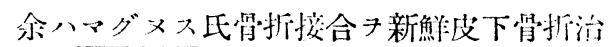

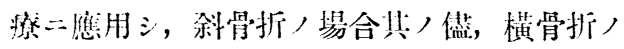

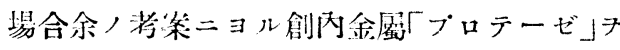
脈湖三，一時性組織內異物址設皮膚真通固定 法ニョリ, 理論的疑懼セラルル化膿傳染子起 ス事ナク治掊七ル數例, 經驗フ報告シ, 本法 ，長管狀婴斜管折，横骨折及ビ陳售骨折，觀 血的撩法トシテ應用スルニ價値フル事害タ示

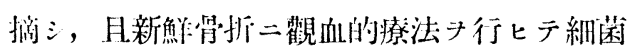
集染化膿, サシテ恐ルルぶキニ非ザルチ云ハ ントス.

\section{第 2 章 概 論}

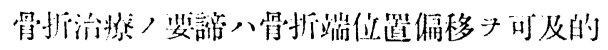
二除上，解湖學的，生理學的正位置二復訾(整
復 Reposition) セシメ，化骨形成二ヨル骨折 端攀合スル期閒 此位置二保持 (Retention) 七 シムルト共二患肢! 自他働的連针 7 可及的早 期ヨリ營マシメ，骨折近接關節若ク八患肢, 筋, 腱, 血管, 神經系統師于軟部組織, 强直 策養障碍キ潰残七シムル事無ク, 完全ナル生 理的機能恢復フ計ルニアリ，骨折治療二際シ 近接關節及ビ軟部組織系統ノ機能 考慮セズ シテ，之等二著シキ病的變化キ續發セシムル ガ如キ事アラバ, 如何二骨折癒着が優秀二解 剖學的成:位置ニアラシメ得タリトスルモ其， 治燃法タル十合理的ナリト八稱シ得ベカラザ ル八明膫ノ事ナリ. 從テ非筧血的療法二於ヶ ル固定二副木硬化縌帶, 若ク八其, 他使肘 スル場合二八必菖ナル期間フ限リ速二之等丹 除去シ，骨折後療法二移行スベキハ言キ侯夕 ザル所ナリ。

骨折療法就中皮下新鮮量折汸療二非觀血的 站二觀血的ノ二途アリ。觀血的療法ニアリテ 八骨折部，整復固定的確二シテ，且强固二企 テ得ルガ故二, 從テ早期ョリ營マシ得ル患肢 ノ自他働的運動ニョリテ關節 及ビ 軟部組織 障碍, 危險キ除キ得ル,長所アリト踓モ, 理

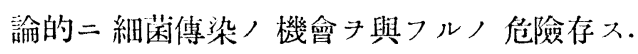
殊二皮膚鿓通固定法二於テ然りト思惟サル。 
非䫏血的䝤法ニアリテハ之等，俈險存久ル事 無キモ,整復固定，確賽及ビ强固性年缺キ, H 副木若クハ其，他，種々ナル固定縌帶，長期

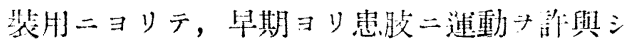
能ハザルノ缺點ン住ス。监折端ノ完全ナル整 微及ビ確實ナル固定八具，治隐機轉子著シク 速カナラシタ，两剩化骨形成 (Callus luxurians）ヌ防ギ，從テ軟部組織，强㨁變化ヲ著三

ク減殺シ得ルハ是义明カ十ル事ナリ。

骨折觀血燃法二努力スル人々ニトウフイエ (Tuffier), ランボット(Lambotte), ドパージ ㄱ (Depage), レーン (Lane), 我國二前田, 标 村氏等アリ。コッヘル (Kocher), アーニイヒ (König), レキŁル (Lexer), シュランゲ (Schlange), ネッッェル (Noetzel), パイルーシュ ナイデル(Pfeil-Schneider), ランチイ (Ranzi)，ウイルムス (Wilms) 氏等八其，手術的適 想拉: フ著シク制限シ，他ノ非觀血的如何ナル 才j法ニテモ除去シ得ラレザル骨折端㣂移，骨

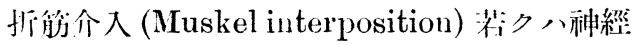

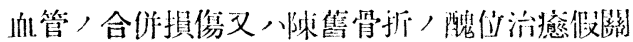
節形成，或八二次的神經洎碍，存ス儿場合二 於テ，ミ传部子肯定セリ。

今齐權威者ニヨリテ認メラレタル手術適應 低シ列舉引用七バ次, 如シ.

A. 新鮮骨折ニアリテハ

1）骨翰橫骨折及ビ多樣骨折ニシテ， 2 週間內二 非雚血的燎法ノ不成二終リタ儿埸合.

2）交錯前膊骨折二テ外的㓳置二テ整復不能，場 合.

3）軟眧組織骨折間介入.

4）極度，偏移 フナセル關節骨折.

5）膝篮骨，跟骨上膊，大絬節，篦嘴哭起，如キ
筋附着部二テ偏移著シキ特。

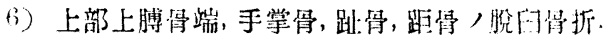

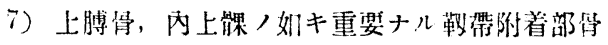
折.

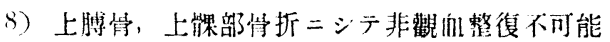
，場合。

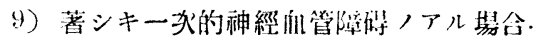

10）小骨折片，關節縉トシテ關節內二剥離七儿勏 合.

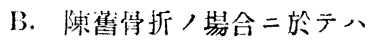

1）機能障碍 7 起七儿醜位治㕍，昜合.

2) 種々ナ儿原因特二限局性原因二シ儿假關珮形 成.

3）主要神經八化骨組織內二圳沒七几䓪合.

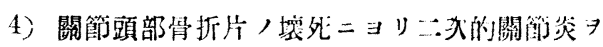
起七儿場合.

5）美精術八見地 $コ$ リ

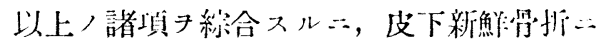

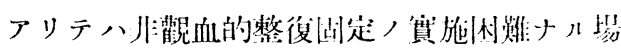

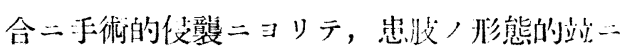
機能的完全恢復子企甼:スルガ稳健尣當ナリト 信ズルモノナリ。

觀血的管折接合法八其，種数多三，而シテ

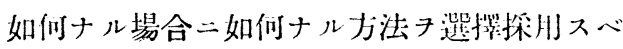
キカハ，骨折型ニョリテ異ナルハ刎論ナルモ 又個人的經驗興味ニ依りテモ異ナル。然レド モ必シモ一力法：ミタ固執スベキモノニ非バ ト信ズ.

今次二觀血的骨接合，種類丹例擧スレバ

1) 骨縫合法 (Die Knochennaht Lejars:- Rahmenartige, Ligatur, Sennscher Knoten).

2) 金屬線繹絡法 (Die Umschnürung mit Draht:Cerclage, Lambotte, L.ejars).

3) 打釷法 (Die Nagelung od. Stütznagel). 
4) 骨折片，直接螺鈳蟐止法 (Die direkte Verschraubung der Fragmente:- Lambotte).

5）金蜜板併用蝶釷締止法（Verschrauhung ïher Motallplatte:- Iransmann, Iane, Lambotte).

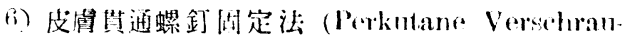
bung mit a. Knodienfeststeller (Fixatemr):I.ambotte, 前田, 木村).

i) 掝子固定法 (Knochenvereinigung clurch Agraffen nach Dujarier).

8）栓固定法 (Knochenbolzung)。木，金，骨栓 7 用>。

9) 同體骨副木 $=ヨ ル$ 接合法 (Vereinigung durch autoplastische Knochenschienen).

以上諸才j法ノ中第 6 項 7 除ク外，接合用筫 物 存續的二組織內二閜销滥設スルガ故二, 臂重無菌操竹ノ下二行ハレシ場合ト踓モ後日 不忙ナル傅染化聩若ク八掼管形成，原因卜 ナルノ恐レアリ. 暴物ノ大サニョリテ其ノ危 險發生率キ異ニスルモ, 其ノ約 20-30\%二於 ラハ後日丽ビ圳設異物フ除去セザル可カラザ ル場合ヨ生ズト說カル。

第 6 項二揭ゲシ皮馓问通周定法ニアリテハ 1855年ランゲンベック，創意ニヨルランボ

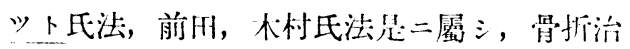

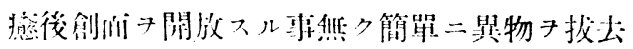
ミ組織冈ニ残留七ミメザル，利アリ。们小月。

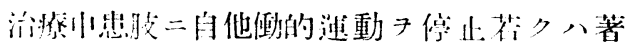

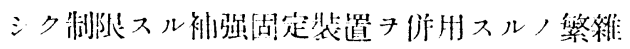
卜不利卜ヨ除キ得一極メテ旦期习リ運動可能 ナルガ故二, 近接關節, 强直若ク八筙肉不䏘

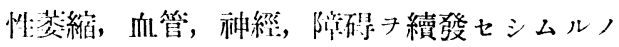
他險ナク完全機能，早期包復尹諒リ得ル，長 所アリト七ラルルモ，使胢期間中常二外界卜
ノ交通路存スルガ雼二細菌潜入热染ノ伦險存

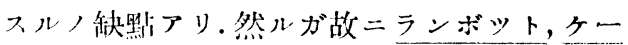

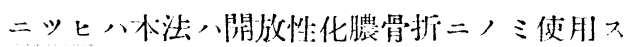

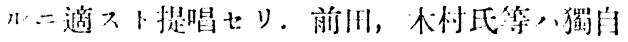

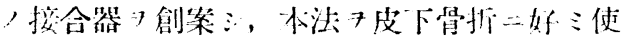

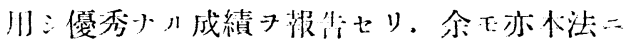
アル不忦ナル化膿傅染八理論的二重っ将へラ ルル程度二隐师的二八遭遇七ズ，從テ大ナル 恐怖キ懷ク要ナキキ信ズルモノナリ。

余，此處二報告七ントスルモノ八皮膚卧 通固定法二蠚スベキモノニシテ，マグメス (Prof. Maginus) 骨接合器チ使朋七ル成績ナ リ。氏ハ多ク假關節手術療法キ推獎セルモ是 フ新鮮骨析二應用シタルモノナリ. 㭕法心其 ，肋具頗簡單ニシテ取扱七又簡易ナリ。盈折

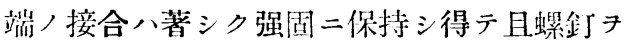
盈質內二打达么事ナキが故二，骨髓ノ椇伤然 ク又往々經驗スル骨質內二金屬釷7打达ミ長 期停留セシムルガ爲二, 此部二起ル骨質二次

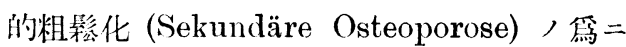

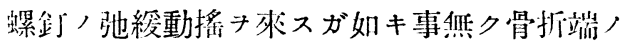
絬合子長期二善二期待シ得ラル。從テ骨折瘾 合，促進头㳳ルト共二邀剩化骨形成 (Callus

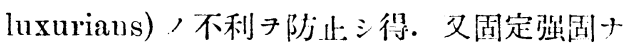

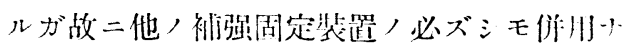

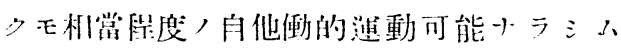

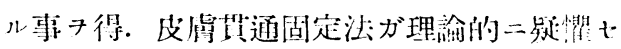
ラルルガ如キ綳藏感染危險ナキモノト七バ， 本法モ办皮下骨折治療殊二長管狀骨斜盈打诜 二余，試ミタル如キ橫骨折治療二隹用スル二 價值アルモノト認メザルタ得ズ. 余八後述細 斨例ニッキ剈足ナル所期，目的子達シ得タル ガ故二，㥒來省ホ多数，實驗例尹要スベキモ 
一先ジー括シテ是キ報告セントス。

\section{第 3 章 用具及ビ術式要旨 (附圖智)}

用具ハマグメス氏ニヨリテ作ラレタルモ，

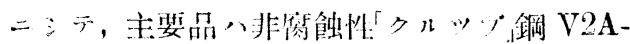

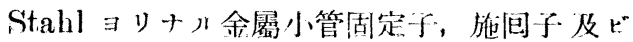

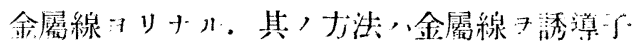

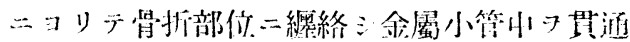

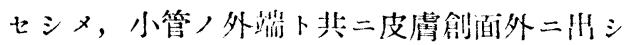
簡單ナル固定子丹通シ，施包子ノ2 簡ノ小孔 二該針金八雨端子通シ，固定子・在拇指卜示 指間二扶持シテ右手ニテ施间子タ趣轉スル。

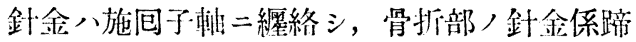
八金屬小管八介在二依りテ强固二締メ付ケラ

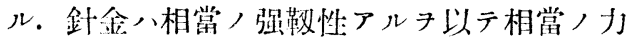
ヨ用フルモ切斷, 虞ナシ。然ル後外小管口二 於テ針金フ單二折り明ゲタルノミニテ針金係 蹄八固定七ラル。剩餘ノ針金み切斷除去シテ 施包子及ビ固定子・取り除クナリ。

骨折治瘾後創內，針金丹除去セントセバ小 管外口/朋折部二テ切斷シ，金屬小管子拔キ 去り㻌金ノ一端子創面近接部ニテ切斷シ, 他 端フ釗子ニテ力强ク把持シテ牽キ拢ク時八容 易二拔去シ得ラルルナリ。

今本器キ唯單ナル埋設式金屬線䌔緮法(Die Umschnürung mit Draht)，目的二使用七 ントセバ (第 5-6 圖參照) 前法ニ於テ㻌金子 小管外口二於テ訮扩スル事無ク，拇指卜示指 トニテ圖，如ク螺施子及ビ固定于・保持シテ 趩轉七心゙針食八强固二繩狀二捻轉ス. 不用部

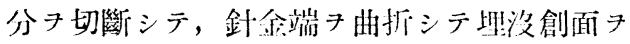
縫合セバ可ナリ・此場合普通用ヒラル鈇み使 师シテ針金子捻轉スル時八若シ過度, 場合二

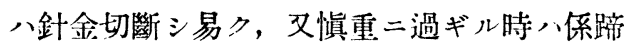
弛緩シテ其ノ目的ヌ達シ得ザルノ短所アリ。 本法二依儿時八過度二捻轉スル時八針金八係 踇部附近二於示絶對二切欮スル事無ク，金䖍

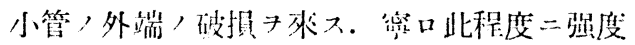
揄轉子行・才，係䠋部强》締り有利十リ卜稃 †ンル.

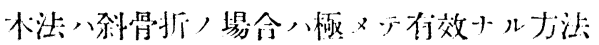

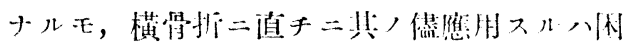

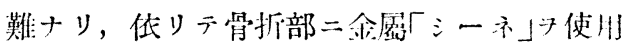

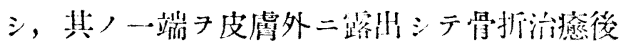
他卜共二除去スル事タ瓶ミタリ。

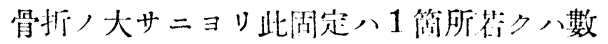
箅所二行ヒテ可ナリ。

手術二際シテハ手術野二於ヶル軟部組織椇 賃赔二不必要ナル骨膜剝離損伤等其，他一般 的注意ニ從フ可キハ勿論ナリ。

\section{第 4 章 臨牀例總括}

余八新鮮骨折例二於テ非雚血们整復周定困 難ナリシ例应二應讨セリ。手術跀期‥般， 指針二從七テ 骨折後 1 週日前後ニシテ, 1 例 二於テ 5 週日間非觀血的處置ニヨリテ不成功 ニ終リタルモノ，骨折部化情組織フ除去三雨 折端，整復固定タ本法後者二從七テ行ヒタル モノアリ。手術時八藏重無菌操作二注意又ル

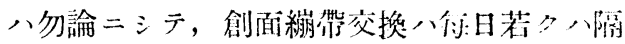

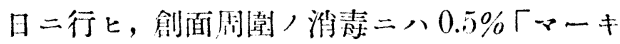

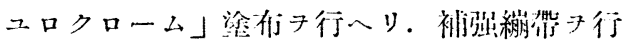
ヒシモノ八早期二除去シテ，患肢，自他侽 的連動キ可及的早期ヨリ營マシムルニ努メタ リ。接合金霓線ハ「レ線憸查ニヨリテ骨，瘾

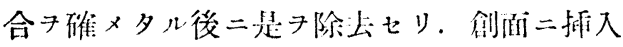


セル业屬管ハムシ口創液, 排出二役立チ, 骨

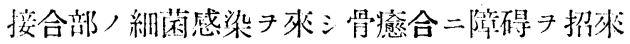
セシメタルガ如キ例症ナシ。骨折治瘾後金線 ，拔上，容易ニシテ，小管及ビ金屬「ブロテー ビ」ンコル孔創闻，除上後極又テ速力二治 痖緼過タトレッ。

\section{第 5 章 臨牀各例}

第1例患葸竹○茂○今 19 筬(「レ」線像 第 1 參照)

診斷 昭和 10 年 11 月 13 日野球練䅛中投球， 際，在上膊骨䔓中央部螺旅形刹骨折.

手術同月 19 日施術. 12 月 19 日金線拔去 $(30$ 日後) 全治退院.

第 2 例 患者 宦○秀○方 42 歲(「レ」線像 第 2 照)

彰斷 昭和 12 年 1 月 15 日外偤. 右上膊骨菱形 骨折片习伴ール螺旋刹骨折.

手術同月 22 日. 2 月 21 日金線拔去(32日後) 全治.

第3 例 患者 前 $\bigcirc$ 淸 $\bigcirc \quad 23$ 歲

診嵝 昭和 11 年 11 月受鹪. 左前膊骨橫骨折. 非 觀血的治療 $习$ 他ニテ受ヶ整復不成功.

手術 昭和 12 年 1 月 11 日施術.「プロテーゼ」 使用. 1 月 12 日( 7 週後)金線除去. 全治.

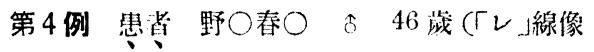
第 3 照)

診燇 昭和 12 年 4 月 29 日材木皘载セ儿本二有 前膊横骨折.

手術5月8日. 6 月8 日企線除去 (30日後). 全治.

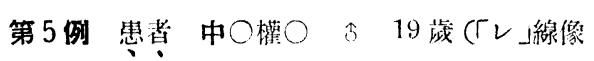
第 4 照)

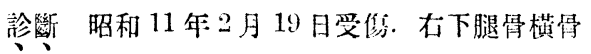
折(遊激骨折片アリ).
手石 3 月 18 日（其＼cjkstart間他二テ非觀血的療法不 成)、鿓通「プロテーゼ」使用.腓骨八脛骨接合後 唯雨端习適應セシメタルノミ。脛骨ノ接合固定ノ 强固ナル 知り得ベシ.

4 月 15 日拔金 $(27$ 日後). 全治.

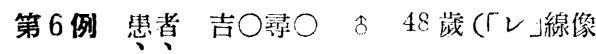
第 6 參照)

诊斷昭和 11 年 7 月 15 日自轉車二テ轉ビ右局

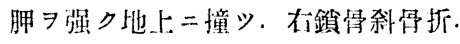

手㷼 7 月 20 日施行. 8 月 12 日(24日後)拢金. 全治.

第7例 患者關○志今8 8 鿊(「レ」線像第 7 參照)

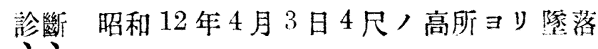
右府胛部 $习$ 撞キ, 右鎖骨横骨折.

手術 他ニテ非觀血的療法 5 月 8 日施術 (受傷後 35 日). 6 月 6 日拔金 $(28$ 日 後). 全治.

\section{第6 章 結 論}

余八「マ」氏骨折接合器キ使用シ，非觀血的

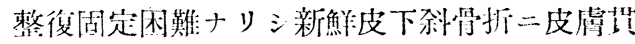
通固定法トシテ應用シ，横骨折／數例ニアリ

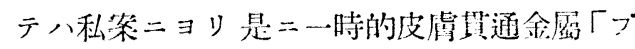

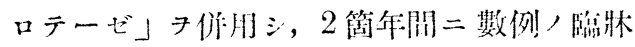

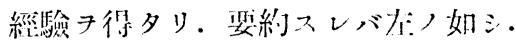

1) 接合操作簡單二シテ整後後骨打端，密

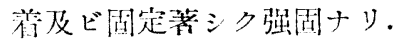

2）從テ骨打澺合速カニシテ目過剩化罗形 成子防止三得ルノ利アリ。

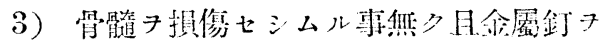
使朋スル事ニヨリテ第二次的骨粗皏化 (Sekundäre Osteoporose) ニヨリテ釷, 弛緩動播

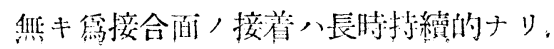


4）創面內, 金屬小管却ッテ「ドレーン」

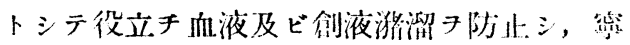
$\mathfrak{n}$ 化澧傅染, 機子少カラシム。

5) 周定中患肢，自他働的渾動子營 マシ

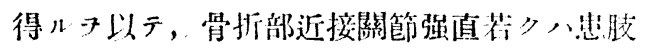

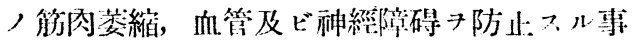
7 得.

6）接合二使用七ル金屬八總テ治癒後容易 二拔去シ得ルガ故二, 組織內二異物遗殘シ後 日異物化膿, 恐 無シ。拔去後, 創面治意八 極メテ汫速ナリ。

7) 大ナル科骨折ノ場合ニアッテハ本法子 2 乃至 4 溦所二使用スル事二ヨツテ, 骨折密i 着固定尹相當程度二期待シ得.

8）橫骨析,場合二ハ「マ」氏接合器ノミニ テハ不可能ナルモ, 私案ニヨル金屬副木テ创
面外ヨリ抑人作用スル事二ヨリテ相當，治憭 成績タ認メタリ。

9）波膚苦通周定法，裴填小，理論的二著 シク恐レラルル傅染路，获通二ヨッテ樵ル卜

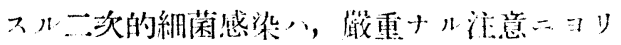

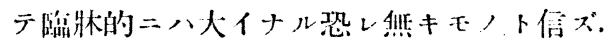

10）觀血的療法八非觀血的橑法，因難ナル 場合二行フォ炃嘗トスベク，且其ノ種類多數 アルモ夫々適應拉ニョッテ哭擇探朋スベキモ ノニシテ，其ノ一キノミ周乹スベキモノニ非 ズ.

11）皮膚莒通周定法ガ一般二疑懼七ラルル 如キ化慨傳染二對シテ，著シキ恐レナシト七 バ本法八價值アルー方法ナリト储信スルモヒ, ナリ.

\section{交}

獻

1) Sonderdruck aus „Chirurgie“, 6. Jahrgang, Heft 1, 1934. 2) H. Matti, Die KnochenFrüche u. ihre Behandlung, (Bd. I-II). 3) Die Nachbehandlung nach (Operationen von Paul Reichel. 4) I.ehrbuch der Chirurgie. Prof. Wulktein u. Prof. Knttner. 5) Allgemeine Chirurgie von lexer. 6) Handbuch der praktischen (hirurgie, Ba. VI u. V. 7) 前田,

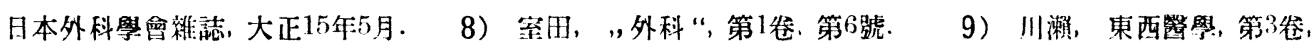
第4 躆。

\section{術式附圖說 明}

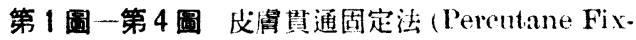
ation) ノ順序 圖説セルモノニシテ，治癔 後使用金屬除去八第 4 圖二於テ，金屬小管 ，外口二於テ針金 7 切斷シ，小管 7 城キ次 デ皮膚面二於テ針金ノ一端 ヨ鍷ニテ持シ針金ヨ钹キ去ルナリ.

第 5 圆一第 6 圖 科骨折埋沒式金屬線纆絡法(Umschnürung mit Draht) ニシテ, 本法/長
所入釗金ノ繩狀撚り杫メテ理想的ニシテ月 係踏习强ク締メ得ル。從來錐二テ釗金 7 把 持シテ針金习然リタルモ，此方法ニテハ强 ク捻轉スル時八錸二テ䤠金 7 破損シ切斷シ 易ク，愹重二力 7 加へザレバ强ク針金係踓 ᄏ締メル事ガ出來得又缺點アリ.

第 7 圖 私案 $=ヨ ル$ 皮有外貫通金屬「シーネ」 7 使用 シ，橫骨折二應用セル埸合 7 圖觀セルナリ。 
術式附圖
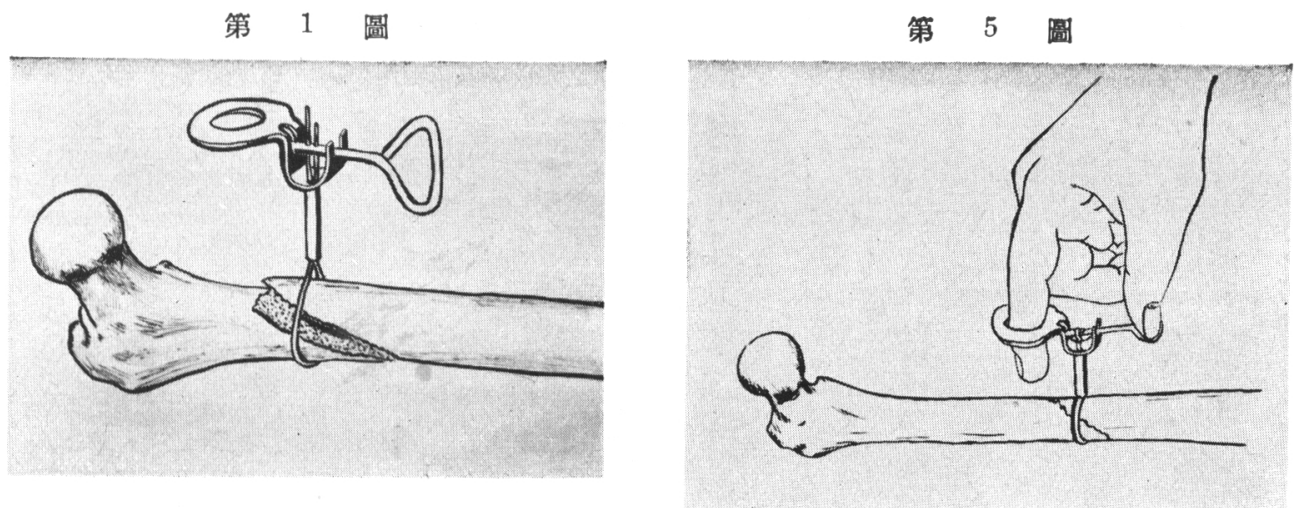

第 2 圆

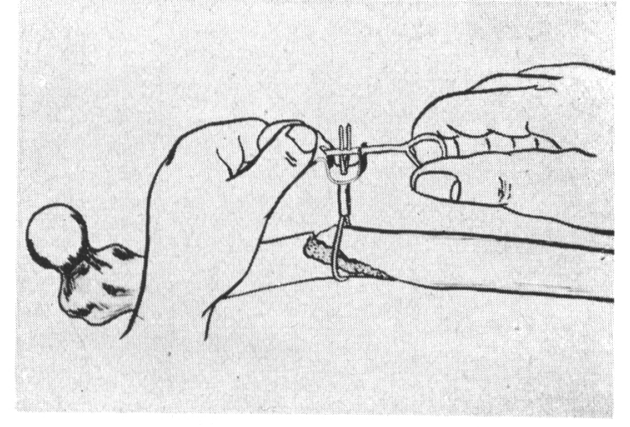

第 3 圖

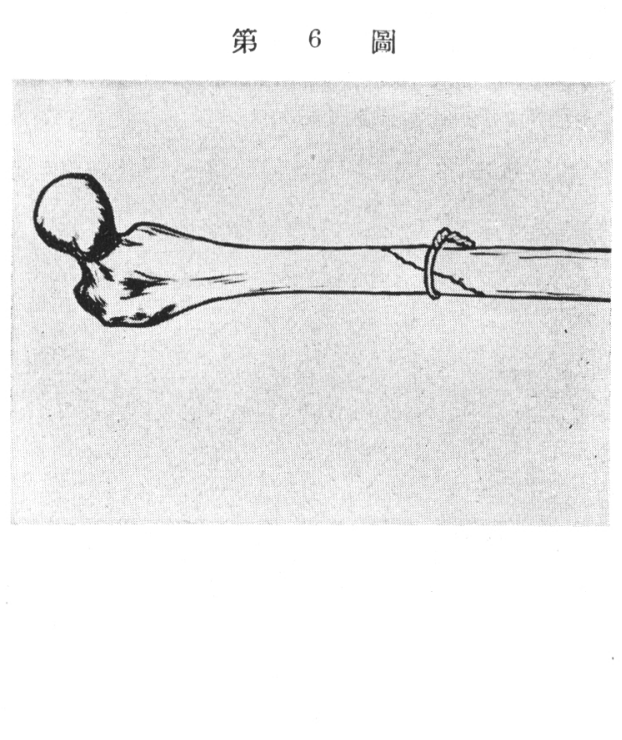

第 4 圖

第 7 圖
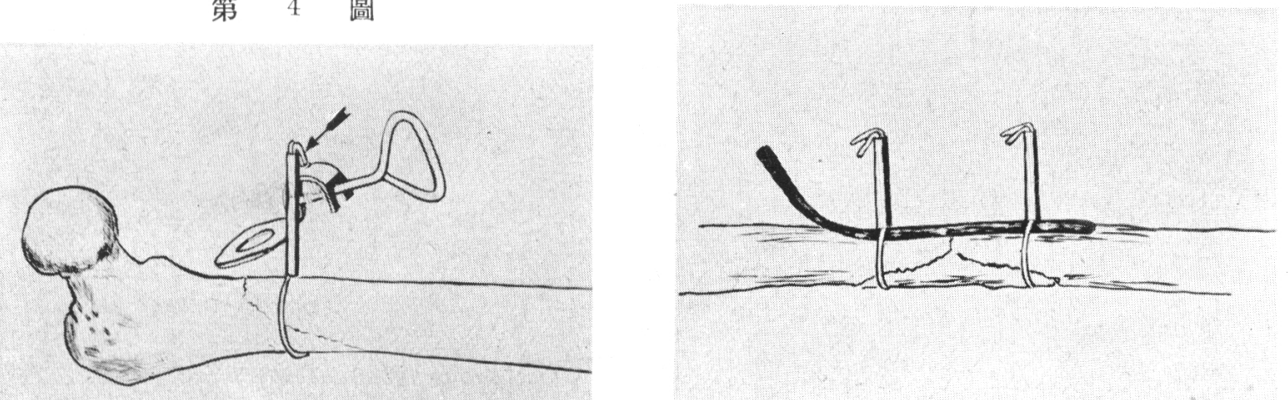


\section{川瀨論文附圖}

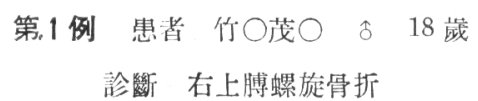

術

前
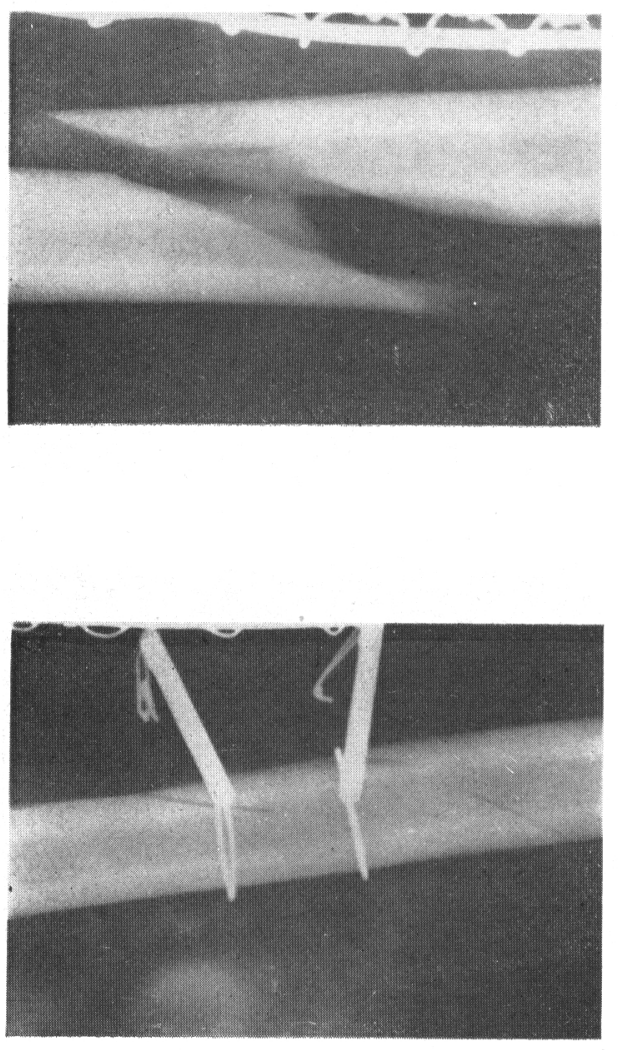

術後 5 䓢日

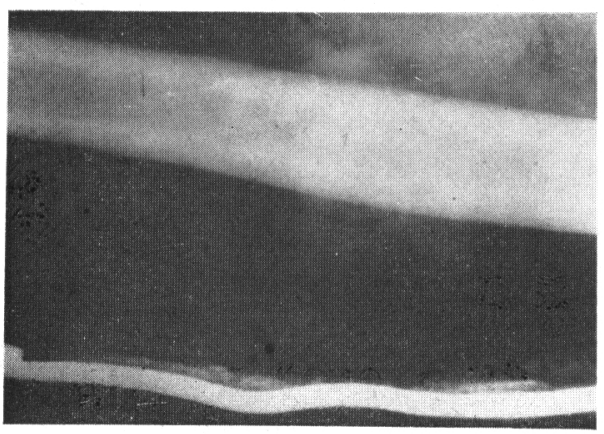

第2例 患者宮○秀○合42歲

部斷 右上膊螺旋骨折

術前
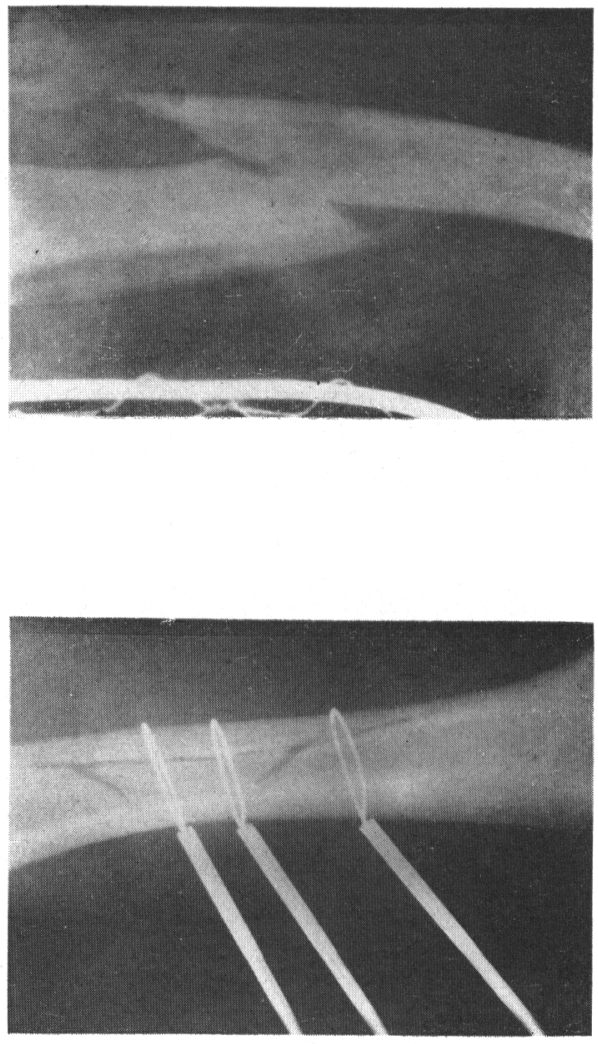

術後 32 日

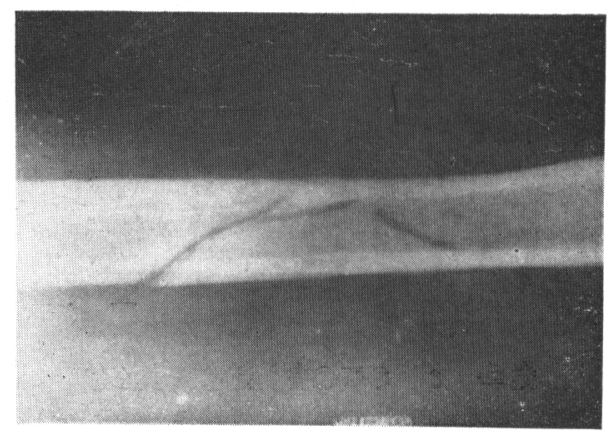




\section{川瀨論 文附圖}

第 4例 患者 野○春 $\bigcirc 46$ 歲

診斷右前膊横骨析

（貫通「プロテーゼ」使用）

石前
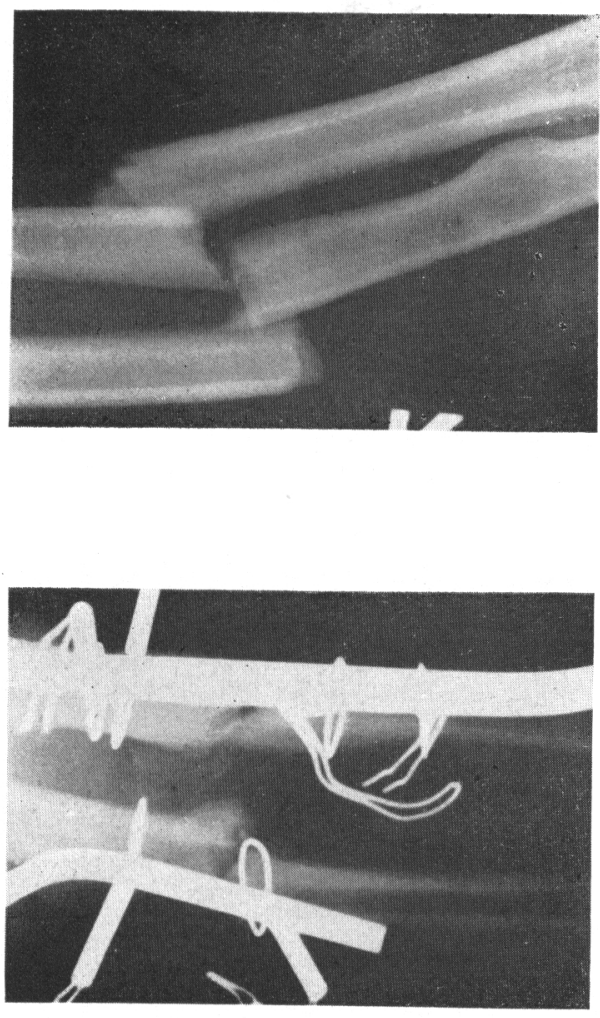

術 後 30 日

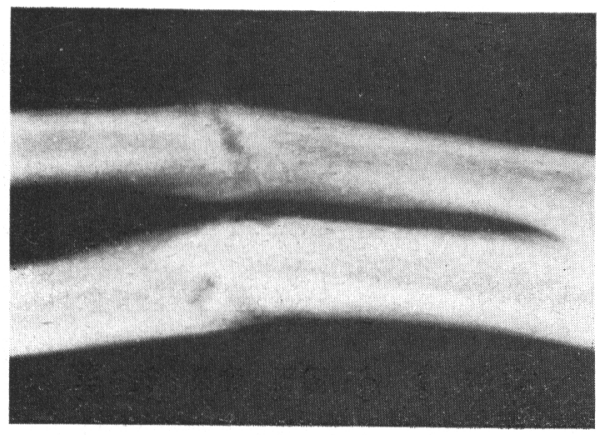

第5 例 患者 中○權○ 819 歲

猃斷右下腿横骨析

（貫通「プロテーゼ」使用）

術前
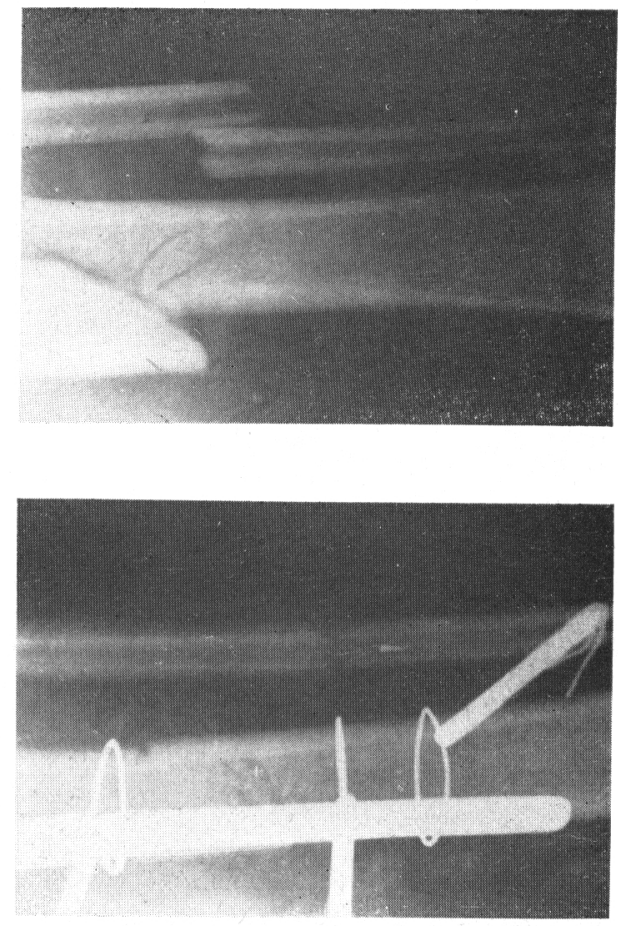

腓骨八脛骨固定强固ナル故二, 特二 固定法习行ハズ骨折面习接着セシム ルノ

術 後 27 日

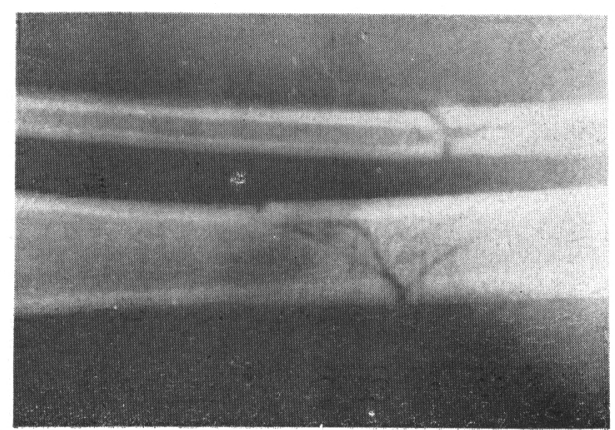




\section{川瀨 論 文附 圖}

$$
\begin{aligned}
& \text { 第7例 患者 關○志○吉8 } 8 \text { 歲 } \\
& \text { 晾践右躀骨横骨折 } \\
& \text { （貫通「プロテーゼ」使用） }
\end{aligned}
$$

(受鹪後 35 日手術)

\section{第6 例 患者 吉○封○合 48 戰 晾斷 右鎖骨科骨折}

\section{術前}

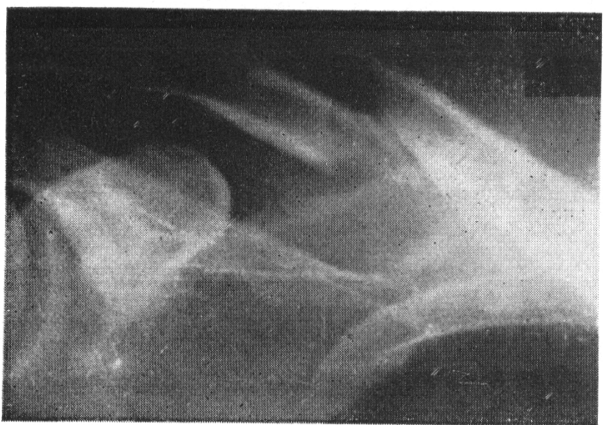

術後 24 日後除去

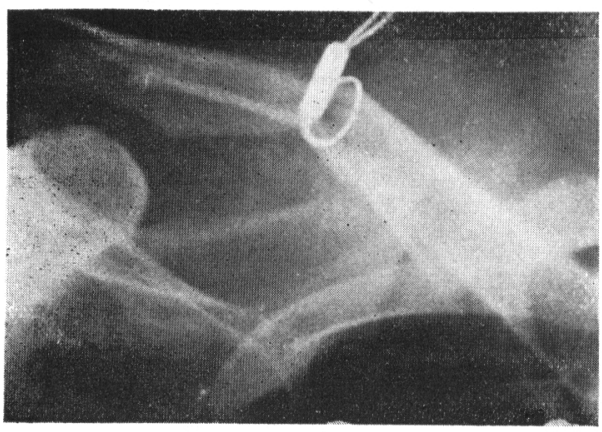

術前
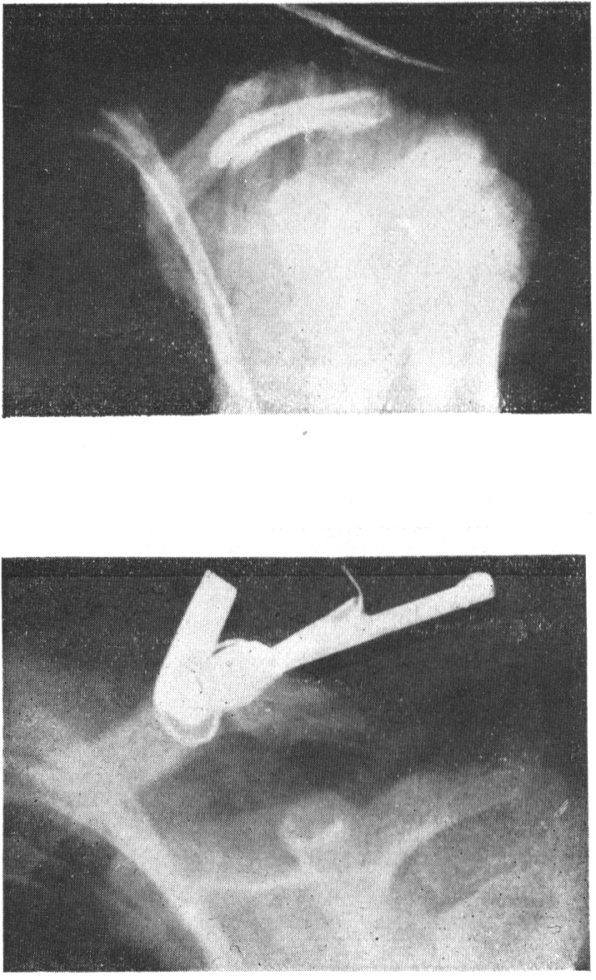

術後 28 日

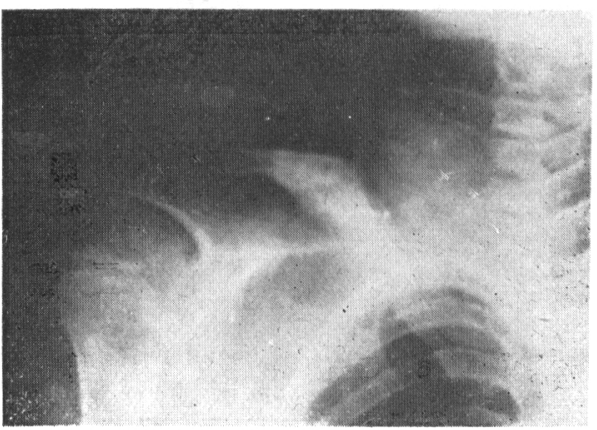

